\title{
Job's Satisfaction among Trainers of Public Vocational Training Institutes in Greece
}

\author{
Panteleimon Bakirtzoglou ${ }^{1}$, Panagiotis Ioannou ${ }^{2}$ \\ ${ }^{1}$ Aristotle University of Thessaloniki, School of Physical Education and Sports Science, Thessaloniki, Greece \\ 2 University of Patras, Department of Primary Education, Patra, Greece \\ bakirtzoglou@phed.auth.gr, pan.ioannou77@gmail.com
}

\begin{abstract}
The purpose of the present study was to investigate the effect of the personnel, interpersonal and organizational factors in job satisfaction among trainers of public Vocational Training Institutes in the city of Thessaloniki. Sample consisted of 300 adults' trainers with a mean age of 40.3 years. Job's satisfaction was used as an independent variable while as dependent variables personnel(age, sex, educational level, marital status, number of children, educational level, profession and teaching experience), interpersonal (relationships with trainees, relationships with co-educators, relationship with the administration, personal development and professionalism) and organizational factors (salary, building structure and working conditions) were used. Statistical analysis included the use of correlation and regression analysis. Results showed that from the dependent variables only age ( $\mathrm{r}=.342)$, years of working experience in Vocational Training Institutes ( $r=.296)$, relationship with the administration ( $r=.699)$ and working conditions $(r=.690)$ had a significant relationship with adults' trainers' job satisfaction $(\mathrm{p}<0.01)$. Furthermore regression analysis showed that relationship with the manager had the biggest prediction of trainers' total job satisfaction at a percentage of $48.6 \%(\mathrm{r}=.699, \mathrm{p}<0.01)$, working conditions can predict trainers' job satisfaction at a percentage of $47.7 \%(\mathrm{r}=.690)$ and age and teaching experience can predict trainers' total job satisfaction at a percentage of $20 \%(\mathrm{r}=.014, \mathrm{p}<0.05)$. In conclusion adults' trainers' total job satisfaction in Vocational Training Institutes in Greece, is influenced mostly by interpersonal (relationship with the administration) and organizational factors (working conditions).
\end{abstract}

\section{Keywords: Administration, working conditions, teaching experience, vocational education, adults}

\section{Introduction}

Over the past two decades inter culturalism and multiculturalism at world level, the movement of people and labor (Haque \& Kim, 1995), globalization of markets and economic activities, as well as the rapid changes and developments in all businesses regardless of size, industry or activity, result in the creation of an international and global competition between companies and countries with the aim of improving service quality and reduce labor costs (Sirgy, Lee, Miller, \& Littlefield, 2004; Tsai, 2007). In response to the pressure of globalization, competitive markets, organizations and companies are searching for ways to improve their service quality and exceed customers' expectations (Saccania, Johansson, \& Perona, 2007). According to Meidute-Kavaliauskiene, Aranskis and Litvinenko (2014), service quality is closely related to customers' satisfaction. A strong relationship between service quality improvement and job satisfaction has been found by the researchers (Snipes, Oswald, LaTour, \& Armenakis, 2005; Yee, Guo, \& Yeung, 2015). Furthermore a positive and strong relationship has been found between employees' satisfaction and customers' satisfaction (Ariani, 2015; Schlesinger \& Zornitsky, 1991; Wagenheim, Evanschitzky, \& Wunderlich, 2007).Thus, managerial strategy and markets focus on human factor and more specific on employees and their satisfaction from the working environment, due to its great importance and contribution on the overall service quality and customers' satisfaction (Lam, Zhang, \& Baum, 2001).

Human factor and employee have become a significant business's variables in recent years, resulting rights to work and working conditions, to be considered as a key point for the viability, growth and profitability of the private and public economy (Jackson, 2002).In today's global economy and business sector, more companies are beginning to give importance and gravity field to human factor, employee and its needs, creating policies to increase the level of satisfaction, making thus job satisfaction a critical and important variable to increase business's profit and improving quality of services to customers (Harter, Schmidt, \& Hayes, 2002). Aplethora of theories tried to define and explain the phenomenon of job satisfaction and its causes(Judge \& Church, 2000).An interpretation and definition of job satisfaction could be the positive attitudes or emotional dispositions people gain from working environment, the pleasurable emotional state resulting from the appraisal of one's job as achieving or facilitating the achievement of one's job values, or the extent to which 
people like or dislike their jobs (Locke, 1976, p.1342; Spector, 1997, p.2). Most of the theories tried to explain job satisfaction, have a strong connection with human motives, such as Maslow's hierarchy needs theory, Herzberg's motivator-hygiene theory, Job Characteristics model and the Dispositional Approach (Hackman \& Oldham, 1975; Herzberg, 1966; Judge \& Lanen, 2001; Maslow, 1995).

Job satisfaction is one of the most important variables that affect and determine the satisfaction of a person in the working environment (Banerjee \& Perrucci, 2010), furthermore has significant effect to the quality of life of workers and customers' satisfaction (Ariani, 2015;Narehan, Hairunnisa, Norfadzillah, \& Freziamella, 2014; Tait, Padgett, \& Baldwin, 1989).The significance and importance of job satisfaction is reflected by the large piece of time and part of their everyday life, people and especially workers-employees deal with (Sousa-Poza \& Sousa-Poza, 2000). According to Gazioglou and Tansel (2006), the importance of job satisfaction is demonstrated by positive aspects related to work such as reducing employee's mistakes, the small number of absences from work and increasing employee's productivity. Jobs satisfaction's variables however, are not stable and characterized by their dynamic nature. These variables can be internal nature such as changes in structure, salary, working conditions, leadership, social relationships with co-workers and external nature such as political and economic changes (Mosadeghrad \& Yarmohammadian, 2006; Tabvuma, Bui, \& Homberg, 2014). Review of literature has showed that these variables of job's satisfaction can be categorized as: personal, interpersonal and organizational (Baker, 2007; Crohan, Antonucci, Adelmann, \& Coleman, 1989; Curtis, 2008; Liu \& Ramsey, 2008; Weiss, 1999).

Education is one of the most basic structures of society. Benefits of education are classified in two categories: market and non-market (McMahon, 1998). These benefits can be achieved also, through a satisfied human factor in the working environment (Chaudhari \& Bhaskar, 2016). Teachers are one of the most important parts of human resources in education's system (Ingersoll, 2007).Teachers overall satisfaction from the working environment positive influences students' achievement and creates high quality education (Johnson, Kraft, Papay, 2012). Education's working environment and working conditions related to job satisfaction, have been the subject of numerous studies focus on the factors that motivate teachers to remain in or leave from their work (Boe, Cook, \& Sunderland, 2008; Demirel, 2014; Evans, 1997; Tickle, 2008). It is important to value teachers' job satisfaction because it influences teachers' turnover (Otto \& Arnold, 2005) and quality of teaching (Demirtas, 2010). Most of the surveys about job's satisfaction in the field of education have focused on teachers in Primary, Secondary or university level and their satisfaction from working environment (Carson, Richards, Hemphill, \& Templin, 2016; Crossman \& Harris, 2006;Fuming \& Jiliang, 2007; Papanastasiou \& Zembylas, 2005).

Vocational Training and furthermore adults' training are one of the most important sectors in the field of general education. Vocational Education and Training is defined as any type of job-related learning that raises an individual's productivity, includes all organized activities which help either to a recognized qualification, or gives people skills and abilities necessary and sufficient for the execution of a set of work (Mortaki, 2012; Tsang, 1997). Vocational Training and education can play a major role in empowering people and creating measurable labour market effects, due to their impact on improving employee knowledge and skills and develop a deeper level of behavioral change through transformative learning (Franz, 2010; Johnson, 2015; Martin \& Grubb, 2001). According to Biavaschi et al. (2012), in recent years has seen a substantial increase and interest for the introduction and connection of youth into labour markets, linking in this way education with economy and labour markets and making Vocational Training responding to social and economic demands and needs of globalization (Mouzakitis, 2010).

Benefits of Vocational Education Training are classified into two categories: economic and social. Economic benefits are identified as: professional status and career development, economic growth, labour-market outcomes, employee's productivity, employment opportunities, earnings and firms' performance. Social benefits are identified as: social cohesion, health, crime reduction, individual motivation, life satisfaction and inclusion of disadvantages groups (Cedefop, 2011). Therefore, an advantage of attending Vocational Training Education programs is usually a labour-market outcome such as the reduction of unemployment and inequality and the chance for the employment to advance in a professional hierarchy, known as employability (Dickson \& Smith, 2011). In Greece, post-secondary Vocational Education Training is usually provided by Vocational Training Institutes (IEK). Their programs last five semesters, four of theoretically and laboratory 
training and one of practical training. Each IEK, focus on a particular sector such as applied arts, foodbeverage, tourism-transportation, telecommunications-network and training-coaching athletes and sports. IEK graduates are awarded occupational specialization diplomas at EQF level 5 (Cedefop, 2014).

Due to economic and social benefits of Vocational Training, its significance and importance is reflected in its human recourses which includes trainees and adults' educators. As it already mentioned above, teachers is one of the most important variable in human resources at the field of education. Furthermore, teachers' overall satisfaction has positive and multiple effects in a variety of parameters (personnel, interpersonal and organizational). However, most of the studies focused on teachers' job satisfaction in a primary, secondary or university level. Instead, there is limited research in the field of adult's education and specifically in the field of job satisfaction of adults' trainers at Vocational Training Institutes. Therefore the purpose of the present study is to investigate the effect of the personnel, interpersonal and organizational factors in job satisfaction among adult's educators of public Vocational Training Institutes in city of Thessaloniki.

\section{Methodology}

Participants: Sample consisted of $300(n=300)$ trainers from public Vocational Training Institutes from the prefecture of Thessaloniki, an urban city in Northern Greece. Of the participants, 140 were men (46.7\%) and 160 were women (53.3\%). Simple Random Sampling technique was used for the selection of the sample.

Procedure: Study was conducted during school period 2014-2105, at public Vocational Training Institutes of the Thessaloniki Prefecture. Study's permission was given from the General Secretariat for Lifelong Learning. After the granting of the license preparation of the present study, the researcher visited the premises of all selected Vocational Training Institutes and informed about the purpose and process of the investigation the respective director. Researcher visited the selected Institutes during their daily curriculum and informed trainers for the purpose, the nature, importance of the present study and about the details of the questionnaire. Participants were informed by the researcher that the completion of the questionnaires is anonymous, results will be used for scientific purposes and if they wished they could be informed about the findings of the present investigation. After these clarifications, trainers who wish to participate stated their consent in written form. All the questions contained in the instrument were clear, with clarifications and explanations, if necessary, by the researcher. Questionnaires were distributed in the working area of adults' trainers by the researcher during Vocational Institutes' daily curriculum. Trainers were asked to complete questionnaires in a quite environment, which usually was an empty class of the building. Specified time completing the questionnaires by trainers was approximately 20 minutes.

Data instruments: To evaluate the degree of adult trainers' job satisfaction, questionnaire was constructed by the researcher. Instrument was constructed by choosing questions from the following questionnaires: personnel questions were made according the current literature on job satisfaction, interpersonal questions constructed according to 'My job satisfaction as an educator' (Makri-Mpotsari\& Matsaggouras, 2002) and by 'Teacher Job Satisfaction Questionnaire' (Lester, 1982). Finally, organizational questions selected and constructed from 'Questionnaire of Job Satisfaction' (Papanis \& Rontos, 2005). Questionnaire was constructed in accordance with the purpose and research questions of the present study. Personnel questions, analyze individual data of adult's trainers such as: age, sex, educational level, marital status, number of children, educational level, profession and teaching experience. Interpersonal questions analyze adult trainers' satisfaction about variables such as: relationships with trainees, relationships with co-educators, relationship with the administration, personal development and personal professionalism. Organizational questions analyze adults' trainers' satisfaction about variables such as: salary, building structure and working conditions. Adults 'trainers were asked to answer, choosing from an option on a 5-point Likert scale. Questions required from the participants to rate their job satisfaction with points ranging from $1=$ totally dissatisfied to $5=$ totally satisfied. Validity and reliability of the questionnaire was calculated with Cronbach's alpha index and was found high (0.91) and significant $(\mathrm{p}<0.01)$.

Statistical Analysis: For the purposes of the present study, the statistic package program IBM SPSS Statistics 22.0 version was used. Descriptive statistics were used in order to summarize the mean and standard deviation of variables. Adults' trainers' job satisfaction was chosen as an independent variable, while the dependent variables of the present study were: sex, age, marital status, educational level, number of children, 
profession, teaching experience at Vocational Training Institutes, relationships with the manager, relationships with trainees, relationships with co-educators, trainers' professionalism, building structure, working conditions and salary. Pearson's correlation analysis was used to examine the relationship between the independent and depended variables. Furthermore, Regression analysis was used to investigate the predictive percentage of the independent form the depended variables. Level of significance was set at $\mathrm{p}<0.01$.

\section{Results}

Participants, examined according to their age, sex, marital status, number of children, educational level, profession and teaching experience. Total of the sample was $300(n=300)$. Most of the adults' trainers were females (160) with a mean age of 38.5 years. According to their marital status they were married (53.7\%), did not have children (45\%), had a Master's certificate (38.7\%) according to their educational level, were working at Vocational Training Institutes (48.7\%) according to their profession and they had a teaching experience of 3 years (15.3\%). Correlation analysis was used to investigate the relationship between adults' trainer's job satisfaction and personnel, interpersonal and organizational factors. As it shown (Table 1), from the personnel variables, only age $(\mathrm{r}=.302, \mathrm{p}<0.05)$ and teaching experience $(\mathrm{r}=.296, \mathrm{p}<0.05)$ had a significant relationship with adults' trainers' job satisfaction. Correlation of the other variables with adults' trainer's job satisfaction was found to be low and not significant.

Table 1: Correlation analysis between adults' trainers' job satisfaction and personnel variables

\begin{tabular}{llllllll}
\hline $\begin{array}{l}\text { Adults' } \\
\text { Trainers }\end{array}$ & Age & Sex & $\begin{array}{l}\text { Marital } \\
\text { Status }\end{array}$ & $\begin{array}{l}\text { Number } \\
\text { Children }\end{array}$ & $\begin{array}{l}\text { Teaching } \\
\text { Experience }\end{array}$ & $\begin{array}{l}\text { Educational } \\
\text { Level }\end{array}$ & Profession \\
& $0.342^{*}$ & 0.107 & 0.194 & 0.102 & $0.296^{*}$ & 0.105 & 0.207 \\
\hline
\end{tabular}

${ }^{*} \mathrm{p}<0.05$

The relationship between adults' trainers' job satisfaction and interpersonal variables is presented in Table 2 . As it shown, from the interpersonal variables relationship with the manager had the biggest relationship with adults' trainers' job satisfaction $(\mathrm{r}=.699, \mathrm{p}<0.01)$.

Table 2: Correlation analysis between adults' trainers' job satisfaction and interpersonal variables

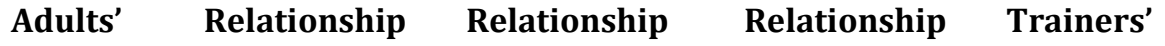

Trainers with trainees with with co- professionalism

administration educators

\begin{tabular}{rrrr}
$0.449^{* *}$ & $0.699^{* *}$ & $0.371^{*}$ & $0.425^{* *}$ \\
\hline${ }^{*} \mathrm{p}<0.05,{ }^{* *} \mathrm{p}<0.01$ & & &
\end{tabular}

The relationship between adults' trainers' job satisfaction and organizational variables is presented in Table 3. As it shown, the relationship between the organizational variables such as salary ( $\mathrm{r}=.451)$, working conditions $(\mathrm{r}=.690)$ and building structure $(\mathrm{r}=.501)$ with adults' trainers' job satisfaction was significant $(\mathrm{p}<0.01)$.

Table 3: Correlation analysis between adults' trainers' job satisfaction and organizational variables

\begin{tabular}{llll}
\hline $\begin{array}{l}\text { Adults' } \\
\text { Trainers }\end{array}$ & Salary & $\begin{array}{l}\text { Working } \\
\text { Conditions }\end{array}$ & $\begin{array}{l}\text { Building } \\
\text { Structure }\end{array}$ \\
\hline & & & \\
& $0.451^{* *}$ & $0.690^{* *}$ & $0.501^{* *}$ \\
\hline${ }^{* *} \mathrm{p}<0.01$ & & &
\end{tabular}

Regression analysis was used to determine the predictive model of trainers' job satisfaction from the depended variables. As it shown in Table 4,from the personnel variables entered the model, only teaching experience at Vocational Training Institutes and age, were the most predictive variables of trainers' job 
satisfaction at a percentage of $20 \%\left(\mathrm{R}^{2}=.14, \mathrm{~b}=.19, \mathrm{p}<.001\right)$. From the interpersonal variables, relationship with the administration could predict and explain adults trainer's total job satisfaction at a percentage of $48.6 \%\left(\mathrm{R}^{2}=.699, \mathrm{~b}=.31, \mathrm{p}<.001\right)$. As for the organizational variables, working conditions could predict adults' trainers job's satisfaction at a percentage of $47.7 \%\left(\mathrm{R}^{2}=.690, \mathrm{~b}=.29, \mathrm{p}<0.01\right)$.

Table 4: Regression analysis between adults' trainers' job satisfaction and personnel, interpersonal and organizational variables

\begin{tabular}{lllll}
\hline Adult's Trainers' Job satisfaction & R & $\begin{array}{l}\text { R Square } \\
\text { Change }\end{array}$ & $\begin{array}{l}\text { Adjusted } \\
\text { R Square }\end{array}$ & Sig. Value \\
\hline Age and Teaching Experience & .143 & .021 & .14 & .003 \\
Relationship with administration & .699 & .486 & .486 & .38335 \\
Working Conditions & .690 & .477 & .475 & .40209 \\
\hline
\end{tabular}

Discussion: The purpose of the present study was to investigate the effect of personnel interpersonal and organizational factors on adults' trainer's job satisfaction working at public Vocational Training Institutes in Greece. Review of the literature has showed that most of the surveys about job satisfaction in the field of education, are mainly referred to primary, secondary and university level (Crossman \& Harris, 2006; Papanastasiou \& Zembylas, 2005), while minimum is the research in the field of adults' education and specifically at Vocational Training Institutes (Bakirtzoglou, 2010).According to Billet (2011), more focus on Vocational Education Training's specific effects is justified. It's perceived status is low. It has received little attention in reforms to education and training systems across Europe (Wolf, 2011). In Greece, last decades an important part of the structure of adults' education takes place through Vocational Training Institutes. According to Cedefop (2012), at 2020 about $60 \%$ of the jobs will require often a vocational nature. This gives much importance to Vocational Training Institutes and education, due to their contribution to economic and social benefits, such as: higher wages, better job prospects, better health and satisfaction with life and leisure for individuals, higher productivity and employee satisfaction for organizations, and higher economic growth and civic engagement for countries (Cedefop, 2013).

The present study focused in the sector of Vocational Education and more specifically at Vocational Training Institutes (IEK) in Greece. Job satisfaction of adults' trainers was examined in relation to multiple variables, due to its significance to trainers' turnover and quality of teaching. Results of the present study showed that of the relationship between personnel, interpersonal and organizational factors with adults' trainer's job satisfaction were significant for few of the variables. From the personnel variables, only age $(\mathrm{r}=.342)$ and teaching experience ( $\mathrm{r}=.296)$ had a significant correlation with adults' trainers job satisfaction. These two variables also can predict and explain trainers' total job satisfaction at a percentage of $20 \%(\mathrm{r}=0.14, \mathrm{p}<0.01)$. This result is in agreement with the majority of the results which refer that variables such as age and teaching experience are significant factors for job satisfaction and teacher's job satisfaction (Berns, 1989; Demirtas, 2010; Glenn, Taylor, \& Weaver, 1977; Grissmer \& Kirby, 1997; Nestor \& Leary, 2000; Sari, 2004; Warr, 1992). It is also in agreement with the findings of Near, Rice and Hunt (1980), which mention teaching experience as an important factor of trainers' job satisfaction in the field of adults' education.

From the interpersonal variable, correlation analysis showed that relationship with the administration had the biggest relationship with trainers' job satisfaction $(\mathrm{r}=.699, \mathrm{p}<0.01)$ and predicts also at a percentage of $48.6 \%$ trainers' total job satisfaction. Earlier surveys showed the importance of leadership and management style on teachers' job satisfaction (Hean \& Garrett, 2001; Moore-Johnson \& Birkeland, 2003; Loeb, DarlingHammond, \& Luczak, 2005). In the field of adults' education the results of a survey also indicated the importance of the administration for trainers' job satisfaction (Tziner \& Latham, 1989).Moreover, according to transformative learning and transformational leadership, Vocational Education trainers and their relationship and interaction with leadership and administration is of great importance and interest, due to the contribution of administration to their personal development, goals, self-efficacy (Mezirow, 1997; Oude Groote Beveborg, Sleegers, \& Van Veen, 2015), personal empowerment (Thoonen, Sleegers, Oort, Peetsma, \& Geijsel, 2011), and collaboration to achieve team and organizational objectives (Hodge, 2011).Therefore, our result is in agreement with transformative learning and leadership theories, as already mentioned. Furthermore, according to job satisfaction's theories our results are in agreement with Herzberg's motivator hygiene theory (1966), which suggests that hygiene variables such as quality of management contribute to 
job satisfaction.

The relationship with the co-trainers and adults was not significant in the present study. This finding is different with the findings of surveys in the field of Primary or Secondary education, which showed that the relationship with co-teachers, colleagues contributes positive and significantly to teachers' job satisfaction and their empowerment(Hean \& Garrett, 2001; Rhodes, Nevill, \& Allan, 2004; Zembylas \& Papanastasioy, 2006).Our result is also in disagreement with Herzberg's motivator hygiene theory (1966), which suggests that hygiene variables such as interaction with colleagues are a parameter of job satisfaction. As for the organizational variables of the present study, correlation analysis showed that working conditions had the biggest relationship with trainers' job satisfaction $(\mathrm{r}=.690, \mathrm{p}<0.01)$ and predicts also trainers' total job satisfaction at a percentage of 47.7\%.According to Bacotic and Babic (2013), working conditions are an important factor influencing job satisfaction, while Liu and Ramsey (2008) referred that bad working conditions may cause stress and reduce educators' job satisfaction. Therefore, our result is in agreement with these surveys and their findings about the importance of working conditions with job satisfaction in the field of general education. Furthermore, this result is in agreement with Herzberg's motivator hygiene theory (1966), which suggests that variables such as working conditions contribute to job satisfaction, when this variable is high.

Another finding in the present study was that form organizational variables, salary had a moderate and significant relationship with trainer's total job satisfaction $(r=0.45, p<0.01)$. Some surveys in the field of adults' education have showed the importance of salary on trainer's total job satisfaction (Bakirtzoglou, 2010; Gerhart, 1987). Many surveys also in the field of education, showed the importance of salary on job satisfaction (Baker, 2007, Kyriacou, Kune, Stephens, \& Hultgren, 2003; Ofovwe, Ofili, Ojetu, \& Okosun, 2013; Page \& Page, 1982). Therefore, our result is in agreement with the findings of these surveys. Results of the present study clearly indicate that interpersonal variables have the biggest contribution on trainer's total job satisfaction. From the interpersonal variables, relationship with the administration found to have the biggest prediction on trainer's total job satisfaction, while relationship with co-trainers was the second variable in regression analysis model. A third result was that organizational variables such as working conditions had the second significant prediction of trainer's total job satisfaction. According to Volmari and Fekete (2009), Vocational Education Training leaders and administration, have a significant contribution to trainer's performance and satisfaction from the working environment, while working conditions can predict trainer's total job satisfaction in a second step, after administration. Therefore, a mix model of interpersonal and organizational factors is positively and strong related to total job satisfaction of adults' trainers in Greece.

\section{Conclusion}

According to the results of the present study, a complex mixed model of interpersonal and organizational variables influence adults' trainers' job satisfaction. It seems that adults' trainer's job satisfaction is influenced mainly from interpersonal and organizational variables rather than personnel. Interpersonal variables such as relationship with the administration is the factor that mainly influences adults' trainers total job satisfaction, while organizational factors, such as working conditions influences in a second step trainers' total job satisfaction. Moreover, personnel variables had a small effect, according to the results of the present study. Due to the importance and significant contribution of the interpersonal variable (relationship with the administration) on adults' trainers total job satisfaction, we suggest that more emphasis should be given by adults' trainers in the administration and the relationship between them. A guideline to achieve this objective is that administration of Vocational Training Institutes should adopt and use the principles of transformational leadership and transformative learning and therefore, emphasize to the activation of all human resources and more specific to adults' trainers and strengthening their high-level needs and motives, to formulate shared goals, to inspire the common vision on their personnel needs and targets and combine the interaction and way of communication with trainers' life experiences (Bass \& Avolio, 1994b; Lavrysh, 2015; Sergiovanni, 1991, p.125; Thoonen et al., 2011).On the other side, we suggest that adults' trainers should improve their daily communication and interaction with the administration, due to the importance of leadership on their professionalism and satisfaction of the working environment. 
Due to the significant relationship of organizational variables (working conditions) and adults' trainers satisfaction was found in the present study, we suggest that the administration of General Secretariat for Lifelong Learning in cooperation with the administration of each Vocational Training Institute, should emphasize to the improvement of the working conditions, due to their impact on trainers' physical, mental and overall satisfaction. Finally, more studies should focus in the relationship between those variables and trainers' job satisfaction in Greece in the field of Vocational Education, due to the importance of job satisfaction in trainers' turnover, motives for teaching, quality of life and also the relationship between labour-market, employment and Vocational Training.

\section{References}

Ariani, D. W. (2015). Employee satisfaction and service quality: Is there relations? International Journal of Business Research and Management, 6(3), 33-44.

Bacotic, D. \& Babic, T. (2013). Relationship between working conditions and Job satisfaction: The case of Croatian Shipbuilding Company. International Journal of Business and Social Science, 4(2), 206-213.

Baker, V. D. (2007). Relationship between job satisfaction and the perception of administrative support among early career secondary choral music educators. Journal of Music Teacher Education, 17(1), 7791.

Bakirtzoglou, P. (2010). Physical Education Teacher's profile working as a trainer at public Vocational Training Institutes and his attitude toward vocational training and adults' education. Paper presented at the $18^{\text {th }}$ International Conference of Physical Education \& Sports, School of Physical Education \& Sports Sciences, Democritus University of Thrace, 21-23 May, Komotini.

Banerjee, D. \& Perrucci, C. C. (2010). Job satisfaction: Impact of gender, race, worker qualifications, and work context, in Christine L. Williams, Kirsten Dellinger (ed.) Gender and Sexuality in the Workplace (Research in the Sociology of Work, Volume 20) Emerald Group Publishing Limited, pp.39 - 58.

Bass, B. M. \& Avolio, B. J. (1994b). Transformational leadership and organizational culture. International Journal of Public Administration, 17, 541-554.

Berns, R. G. (1989). Job satisfaction of vocational education teachers in northwest Ohio. Bowling Green, OH: Bowling Green State University, Northwest Ohio Vocational Education Personnel Development Regional Center.

Biavaschi, C., Eichhorst, W., Giulietti, C., Kendzia, M. J., Murayev, A., Pieters, J., Rodriguez-Planas, N., Schmidl, R. \& Zimmermann, K. F. (2012). Youth unemployment and vocational training. IZA Discussion Paper. DP No. 6890.

Billet, S. (2011). Vocational Education: purposes, traditions and prospects. Dordrecht: Springer.

Boe, E., Cook, L. \& Sunderland, R. (2008). Teacher turnover: Examining exit attrition, teaching area transfer, and school migration. Exceptional Children, 75(1), 7-31.

Carson, R. L., Richards, K. A. R., Hemphill, M. A. \& Templin, T. (2016). Exploring the job satisfaction of late career secondary physical education teachers. Journal of Teaching in Physical Education, 35(3), 70-75.

Cedefop. (2011). Exploring leadership in Vocational Education and Training. Luxemburg: Publications Office of the European Union. Research Paper: No. 13.

Cedefop. (2011). The benefits of Vocational Education and Training. Luxemburg: Publications Office of the European Union. Cedefop Research Paper: No. 10.

Cedefop. (2012). Future skills supply and demand in Europe: forecast 2012. Luxemburg: Publications Office of the European Union. Research Paper: No. 21.

Cedefop. (2013). Benefits of Vocational Education and Training in Europe, for people, organizations and countries. Luxemburg: Publications Office of the European Union.

Cedefop. (2014). European Centre for the Development of Vocational Training. Vocational Education and Training in Greece. Short description. Luxemburg: Publications Office of the European Union.

Chaudhari, N. S. \& Bhaskar, P. (2016). Training and development and job satisfaction in education sector. Journal of Resources Development and Management, 16, 42-45.

Crohan, S. E., Antonucci, T. C., Adelmann, P. K. \& Coleman, L. M. (1989). Job characteristics and well-being among women at midlife: Gender and Race comparisons. Psychology of Women Quarterly, 13(2), 223235.

Crossman, A. \& Harris, P. (2006). Job satisfaction of secondary school teachers. Educational Management Administration Leadership, 34(1), 29-46. 
Curtis, E. A. (2008). The effects of biographical variables on job satisfaction among nurses. British Journal of Nursing, 17(3), 174-180.

Demirel, H. (2014). An investigation of the relationship between job and life satisfaction among teachers. Procedia Social and Behavioral Sciences, 116, 4925-4931.

Demirtas, Z. (2010). Teachers' job satisfaction levels. Procedia Social and Behavioral Sciences, 9(1), 10691073.

Dickson, M. \& Smith, S. (2011). What determines the return to education: an extra year or a hurdle cleared? Economics of Education Review, 30(6), 1167-1176.

Evans, L. (1997). Understanding teacher morale and job satisfaction. Teaching and Teacher Education, 13(8), 831-845.

Franz, N. (2010). Catalyzing employee change with transformative learning. Human Recourse Development Quarterly, 21(1), 113-118.

Fuming, X. \& Jiliang, S. (2007). Research on job satisfaction of elementary and high school teachers and strategies to increase job satisfaction. Chinese Education \& Society, 40(5), 86-96.

Gazioglou, S. \& Tansel, A. (2006). Job satisfaction in Britain. Applied Economics, 38(10), 1163-1171.

Gerhart, B. (1987). How important are dispositional factors as determinants of job satisfaction? Implications of job design and other personnel programs. Journal of Applied Psychology, 72(3), 366-373.

Glenn, N. D., Taylor, P. A. \& Weaver, C. D. (1977). Age and job satisfaction among males and females: A multivariate, multisurvey study. Journal of Applied Psychology, 62(2), 189-193.

Grissmer, D. \& Kirby, S. N. (1997). Teacher turnover and teaching quality. Teachers College Record, 99(1), 4556.

Hackman, J. R. \& Oldham, G. R. (1975). Development of the Job Diagnostic Survey. Journal of Applied Psychology, 60(2), 159-170.

Haque, N. U. \& Kim, S. J. (1995). Human capital flight- impact of immigration on income and growth. International Monetary Fund Staff Papers, 42(3), 577-607.

Harter, J. K., Schmidt, F. L. \& Hayes, T. L. (2002). Business-unit-level relationship between employee satisfaction, employee engagement, and business outcomes: A meta-analysis. Journal of Applied Psychology, 87(2), 268-279.

Hean, S. \& Garrett, R. (2001). Sources of job satisfaction in science secondary school teachers in Chile. Compare: A Journal of Comparative and International Education, 31(3), 363-379.

Herzberg, F. (1966). Work and the Nature of Man. Cleveland, World Publishing Company.

Hodge, S. (2011). Learning to manage: Transformative outcomes of competency-based training. Australian Journal of Adult Learning, 51(3), 498-517.

Ingersoll, R. M. (2007). Short on power, long on responsibility. Educational Leadership, 65(1), 20-25.

Jackson, T. (2002). The management of people across cultures: Valuing people differently. Human Resource Management, 41(4), 455-475.

Johnson, E. J. (2015). Empowerment of women through Vocational Training. Basic Research Journal of education Research and Review, 4(2), 37-44.

Johnson, S. M., Kraft, M. A. \& Papay, J. P. (2012). How context matters in high-need schools: The effects of teachers' working conditions on their professional satisfaction and their students' achievement. Teachers College Record, 114(10), 1-39.

Judge, T. A. \& Church, A. H. (2000). Job satisfaction: Research and practice. In C. L. Cooper \& E. A. Locke (Eds.), Industrial and organizational psychology: Linking theory with practice (pp. 166-198). Oxford, UK: Blackwell.

Judge, T. A. \& Lanen, J. R. (2001). Dispositional affect and Job Satisfaction: A review and theoretical extension. Organizational Behavior and Human Decision Processes, 86(1), 67-98.

Kyriacou, S., Kunc, R., Stephens, P. \& Hultgren, A. (2003). Student teachers' expectations of teaching as a career in England and Norway. Educational Review, 55(3), 255-263.

Lam, T., Zhang, H. \& Baum, T. (2001). An investigation of employees' job satisfaction: the case of hotels in Honk Kong. Tourism Management, 22(2), 157-165.

Lavrysh, Y. (2015). Transformative learning as a factor of lifelong learning by the example of Vocational Education in Canada. Comparative Professional Pedagogy, 5(4), 62-67.

Lester, P. E. (1982). Teacher Job Satisfaction Questionnaire. Long island University, Brookville, New York.

Liu, X. S. \& Ramsey, J. (2008). Teachers' job satisfaction: Analyses of the Teacher Follow-Up Survey in the United States for 2000-2001. Teaching and Teacher Education, 24(5), 1173-1184. 
Locke, E. A. (1976). The Nature and Causes of Job Satisfaction. In Dunnette, M.P. (Ed.) Handbook of Industrial and Organizational Psychology (pp.1297-1350), Chicago: Rand McNally.

Loeb, S., Darling-Hammond, L. \& Luczak, J. (2005). How teaching conditions predict teacher turnover in California Schools. Peabody Journal of Education, 80(3), 44-70.

Makri-Mpotsari, E. \& Matsagouras, H. (2002). Self-perception's and primary educators' job satisfaction structure. Paper presented at the $3^{\text {rd }}$ Hellenic Conference of Hellenic Pedagogy and Educational Research, 7-9 November, Athens.

Martin, J. P. \& Grubb, D. (2001). What works and for whom: A review of OECD countries' experience with active labour market policies. Swedish Economic Policy Review, 8(2), 9-56.

Maslow, A. (1995). Motivation and Personality. New York: Harper.

McMahon, W. C. (1998). Conceptual framework for the analysis of the social benefits of lifelong learning. Education Economics, 6(3), 309-346.

Meidute-Kavaliauskiene, I., Aranskis, A. \& Litvinenko, M. (2014). Consumer satisfaction with the quality of logistic services. Procedia-Social and Behavioral Sciences, 110, 330-340.

Mezirow, J. (1997). Transformative learning: Theory to practice. New Directions for Adult and Continuing Education, 74, 5-12.

Moore-Johnson, S. \& Birkeland, S. E. (2003). Pursuing a sense of success: New teachers explain their career decision. American Educational Research Journal, 40(3), 581-617.

Mortaki, S. (2012). The Contribution of Vocational Education and Training in the Preservation and Diffusion of Cultural Heritage in Greece: The Case of the Specialty "Guardian of Museums and Archaeological Sites. International Journal of Humanities and Social Sciences, 2(24), 51-58.

Mosadeghrad, A. M. \& Yarmohammadian, M. (2006). A study of relationship between managers' leadership style and employees' job satisfaction. Leadership in Health Services, 19(2-3), xx-xxviii.

Mouzakitis, G. S. (2010). The role of vocational education and training curricula in economic development. Procedia-Social and Behavioral Sciences, 2(2), 3914-3920.

Narehan, H., Hairunnisa, M., Norfadzillah, R. A. \& Freziamella, L. (2014). The effect of quality of work (QWL) programs on quality of life (QOL) among employees at multinational companies in Malaysia. Procedia-Social and Behavioral Sciences, 112, 24-34.

Near, J. P., Rice, R. W. \& Hunt, R. G. (1980). The relationship between work and nonwork domains: A review of empirical research. Academy of Management Review, 5(3), 415-429.

Nestor, P. I. \& Leary, P. (2000). The relationship between tenure and non-tenure track status of Extension faculty and job satisfaction. Journal of Extension, 38(4), Article 4RIB1.

Ofovwe, C. E., Ofili, A. N., Ojetu, O. G. \& Okosun, F. E. (2013). Marital satisfaction, job satisfaction and psychological health of secondary school teachers in Nigeria. Health, 5(4), 663-668.

Otto, S. J. \& Arnold, M. (2005). A study of experienced special education teachers' perceptions of administrative support. College Student Journal, 39(2), 253-259.

Oude Groote Beveborg, A., Sleegers, P. J. C. \& Van Veen, K. (2015). Promoting VET teachers' individual and social learning activities: The empowering and purposeful role of transformational leadership, interdependence and self-efficacy. Empirical Research in Vocational Education and Training, 7(5), 120.

Page, F. M. Jr. \& Page, J. A. (1982). Perceptions of teaching that may be influencing the current shortage of teachers. College Student Journal, 16(4), 308-311.

Papanastasiou, E. C. \& Zembylas, M. (2005). Job satisfaction variance among public and private kindergarten school teachers in Cyprus. International Journal of Educational Research, 43(3), 147-167.

Papanis, E. \& Rontos, K. (2005). Psychology-Sociology of working and managing human recourses: Theory and Empirical research. Athens, Sideris Publications.

Rhodes, C., Nevill, A. \& Allan, J. (2004). Valuing and supporting teachers: A survey of teacher satisfaction. Dissatisfaction morale and retention within an English Local Education Authority. Research in Education, 71(1), 67-80.

Saccania, N., Johansson, P. \& Perona, M. (2007). Configuring the after-sales service supply chain: A multiple case study. International Journal of Production Economics, 110(1-2), 52-69.

Sari, H. (2004). An analysis of burnout and job satisfaction among Turkish special school head teachers and teachers, and the factors effecting their burnout and job satisfaction. Educational Studies, 30(3), 291306. 
Schlesinger, L. A. \& Zornitsky, J. (1991). Job satisfaction, service capability and customer satisfaction: an examination of linkages and management implications. Human Resource Planning, 14(2), 141-149.

Sergiovanni, T. J. (1991). The Principalship: a reflective practice perspective. Needham Heights, MA, Allyn and Bacon.

Sharma, R. D. \& Jyoti, J. (2009). Job satisfaction of university teachers: An empirical study. Journal of Services Research, 9(2), 51-80.

Sirgy, M. J., Lee, D. J., Miller, C. \& Littlefield, J. E. (2004). The impact of globalization on a country's quality of life: toward an integrated model. Social Indicators Research, 68(3), 251-298.

Snipes, R. L., Oswald, S. L., LaTour, M. \& Armenakis, A. A. (2005). The effects of specific job satisfaction facets on customer perceptions of service quality: an employee level analysis. Journal of Business Research, 58(10), 1330-1339.

Sousa-Poza, A. \& Sousa-Poza, A. A. (2000). Well-being at work: a cross national analysis of the levels and determinants of job satisfaction. Journal of Socio-Economics, 29(6), 517-538.

Spector, P. E. (1997). Job Satisfaction: Application, assessment, causes and consequences. London: Sage.

Tabvuma, V., Bui, H. T. N. \& Homberg, F. (2014). Adaptation to externally driven change: The impact of political change on Job Satisfaction in the public sector. Public Administration Review, 74(3), 384-395.

Tait, M., Padgett, M. Y. \& Baldwin, T. T. (1989). Job and life satisfaction: A reevaluation of the strength of the relationship and gender effects as a function of the date of the study. Journal of Applied Psychology, 74(3), 502-507.

Thoonen, E. E. J., Sleegers, P. J. C., Oort, F. J., Peetsma, T. T. D. \& Geijsel, F. P. (2011). How to improve teaching practices: The role of teacher motivation, organizational factors and leadership practices. Educational Administration Quarterly, 47(3), 496-536.

Tickle, B. (2008). Public school teacher's perception of administrative support and its mediating effect on their job satisfaction and intent to stay in teaching. Doctoral Dissertation, Blacksburg, Virginia.

Tsai, M. C. (2007). Does globalization affect human well-being? Social Indicators Research, 81(1), 103-126.

Tsang, M. C. (1997). The cost of vocational training. International Journal of Manpower, 1-2, 63-89.

Tziner, A. \& Latham, G. P. (1989). The effect of appraisal instrument, feedback, and goal setting on worker satisfaction and commitment. Journal of Organizational Behavior, 10(2), 145-153.

Volmari, K. \& Fekete, L. (2009). Defining VET professions: VET leadership. Presentation at the CEDEFOP conference Teachers and trainers at the heart of innovations and VET reform. Thessaloniki, 23-24 February.

Wagenheim, F., Evanschitzky, H. \& Wunderlich, M. (2007). Does the employee-customer satisfaction link hold for all employee groups? Journal of Business Research, 60(7), 690-697.

Warr, P. B. (1992). Age and occupational well-being. Psychology and Aging, 7(1), 37-45.

Weiss, E. M. (1999). Perceived workplace conditions and first-year teachers' morale, career choice commitment, and planned retention: a secondary analysis. Teaching and Teacher Education, 15(8), 861-879.

Wolf, A. (2011). Review of Vocational Education. London: Department for Education.

Yee, R. W. Y., Guo, Y. \& Yeung, C. L. (2015). Being close or be happy? The relative impact of work relationship and job satisfaction on service quality. International Journal of Production Ergonomics, 169, 391-400.

Zembylas, M. \& Papanastasiou, E. C. (2006). Sources of teacher job satisfaction and dissatisfaction in Cyprus. A Journal of Comparative Education, 36(2), 229-247. 